\title{
行動薬理学的アプローチによる 時間評価機構の研究
}

\section{岩本隆茂*, 和田博美**}

\section{1. 行動薬理学とは何か}

行動薬理学 (behavioral pharmacology) とは, 動物やヒトの生得性行動や学習性行動に対する薬物 の作用を解明することを目的した, 生理学, 心理学, 薬理学などを関連領域とする学際的学問のUとつで ある ${ }^{1)}$ 。行動薬理学は最近50年間に，行動に及ぼす 薬物の効果に興味を抱いた心理学者, 薬理学者, 生 理学者，精神医学者などを中心にして発展してきた もので, その方法論としては心理学や薬理学におけ る手法, たとえば心理学的手法としては, オペラン 卜条件づけを中心とする実験行動分析法などや古典 条件づけが, 薬理学的手法としては, 中枢神経系に 作用する向精神薬の投与などが，その研究のための 重要な武器として用いられている。

毎年数えきれないほどの新薬が開発，合成されて いるなかで, 実際に治療薬として有用かつ無害なも のをのみスクリーニングする（審査を行って適格な 薬物を選びだす）ことは, 行動薬理学の果すべき重 要な役割の 1 つである。たとえば抗不安薬のスクリ 一ニングでは，実験行動分析法の1つとして電撃回 避学習が用いられる。この手続きでは, 電気ショッ クと中性刺激が対提示され, 条件づけ学習が成立す ると, 動物は中性 (条件) 刺激の提示に対しても回 避反応を示すようになる。この反応は不安動因によ ってひきおこされるものと考えられており，ある薬 物がこの反応の形成を阻害したり消去を促進したり すれば，その薬物が不安減少をもたらしたと考えら れ，抗不安作用の有無を判定することができるので ある。

精神的ストレスを受けることの多い複雑化した現 代社会では, われわれの日常生活と薬物の捸取（と くに精神安定剤や睡眠薬）とは切っても切り離せな
い関係にある。このような現状を考えるならば，行 動薬理学の存在意義はきわめて重要であり, 社会に 対して果すべき責務もまた重大であろう。

\section{2. 行動薬理学の歴史}

薬物使用の起源はきわめて古く，大昔からさまぎ まな種類の薬物一アアルコール(鎮静剤), 夕バコ, コカ(興奮剂), ローウォルフィア (抗精神病薬), カンナビス, ペヨーテ, カクタス (幻覚郕), アヘン (鎮痛剂) 等々一一゙，人間の精神や行動に作用す る物質として経験的に利用されてきた。しかし19世 紀になって近代化学が発達してくると, これら天然 の薬物の成分を分析することが可能となってきた。 その結果, 有効成分が抽出されて化学構造式が決定 され，それに基づいて新しい薬物が実験室で合成さ れるようになった。これらの人工合成薬は，一般に天 然の薬物よりも有効で主作用も副作用もともに強く, たとえば1803年に Sertürner がアヘンから単離に成 功したモルヒネは, アヘンより10倍以上も鎮静効果 が強かった。1898年には，モルヒネよりさらに2.5 倍も強力なへロインが合成されている。1858年には コカの木の葉からコカインが抽出された。コカイン はかつてコカコーラの成分のひとつとして知られて

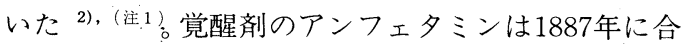
成されている。バルビツール酸は 1864 年に合成され， これをもとにして, バルビタールやバルビツレート など約 2,500 種もの睡眠薬が合成されるようになっ てきた。

そして20世紀の幕開けが訪れると, 正式に行動薬 理学の研究が始まった。その重要な原動力のひとつ として, 動物心理学の学問としての確立があげられ る。多くの生理学者や心理学者は, 学習や行動を分

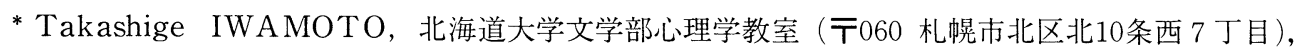

** Hiromi WADA, 北海道大学環境科学研究科衛生学教室 
析，解明する手段の 1 つとして薬物を使用するよう になり，薬物の生理的作用機序に興味を抱いた薬理 学者は, 捸食量, 飲水量, 活動性, 体重などの行動変化 を指標として，薬物の生体影響を分析するようにな つた。Pavlovの研究室では, イ邓の古典条件づけに 及ぼすアルコール, モルヒネ, コカイン, カフェイ ン等の作用が検討され4)，1920年代初めには, Macht らがアへンなどの薬物の影響を迷路学習事態で 研究している ${ }^{5)}$,

1940年代から50年代になると, 行動薬理学の未来 を根本的にかえる偉大な発見があいついでおこった。 フランスの製薬会社スペシア社のChapentier は, 抗 ヒスタミン薬を研究するうちにクロールプロマジン $(\mathrm{CPZ})$ を発見し，アメリカの精力的な精神医学者 Kline は, ローウォルフィアからつくられたレセル ピンの治療効果を見い出した。これらの薬物は精神 分裂病患者に対して劇的効果を現わし, 精神病院の 雾囲気を一変させたのである。行動薬理学の未来を 変えた第 3 の出来事は, 幻覚剂LSDの発見とその 乱用である。1943年, スイスの化学者Hofmann は, 麦角塩基を研究している最中に誤ってこれを攝取し てしまい,「異常な造形と強烈な色彩が万華鏡のよ うにたわむれるといった幻想的な世界」を体験した7)。 このような体験は精神病患者の体験ときわめてよく 類似していたため, 多くの精神医学者たちの注目を 集め, 精神病のモデルとしてLSD の中枢作用が研 究されるようになった1)。しかしその一方で, LSD の使用が一般市民の間にも除々に広まり始め, 1950 年代中頃には不正に大量密造され, 若者の間で享楽 的に用いられるようになってきたのである。

薬理学史上, クロールプロマジンやレセルピンのも たらした影響は強烈だった。そのため政府や製薬会 社は, 行動異常の治療にもっと効果のある新薬の開 発に乗り出した。その努力の効あって, メプロバメ 一ト (1954年), クロルジアゼポキサイト (1960年), ジアゼパム (DZP，1961年) といった抗不安薬がつ ぎつぎに開発されてきた。また1957年には，モノア ミンオキシダーゼ阻害薬や三環系抗うつ薬のイミプ ラミンも製造された。

オペラント心理学の研究法である実験行動分析法 が, 薬物の作用を分析したり臨床上有効な治療効果 の有無を判定したりする上で，きわめて有力である ことが明らかになると, 実験行動分析的薬物試験法 に対する期待と需要が急激に高まり, 各地の大学や 製薬会社に行動薬理学研究室が設置されるようにな
つた。これを契機に行動薬理学は急速な発展を遂げ ることになるのである。オペラント条件づけは, 薬 物の学習性行動に対する分析法としてきわめて敏感 であり，かつまた安定した客観的デー夕をもたらし てくれた。そのため1955年以前には，オペラント条 件づけを用いた研究は行動薬理学的研究全体の $10 \%$ にすぎなかったのに比べて，1955～63年にかけて， いっきに全体の $52 \%$ 占めるまでに普及したのであ る。

1960年代後半になると，LSD をはじめとして多 くの薬物が享楽的な目的で使用されるようになり， とりわけ麻薬や幻覚剂の乱用が一般大衆の間に広ま っていった。その結果, この問題に対処すべく動物 による薬物自己投与という新たな研究領域が生み出 されることになった。Headleeら ${ }^{8)}$ が最初に薬物の 自動腹腔内投与法を確立し, Weeks ${ }^{9)}$ やThompson とSchuster ${ }^{10}$ も，ネズミやサルを用いた静脈内自己 投与法を報告した。この薬物自己投与法では, 動物 が実験者の組んださまざまな強化スケジュール ${ }^{11}$ に 従って適切な反応をすると自動注入装置が作動し, 動物の体内に埋め込まれたカテーテルを通して一定 量の薬掖が注入される。自己投与法による分析の結 果，人間に嗜癖をひきおこした薬物では動物にも自 己投与が生じたが，人間に嗜癖が生じなかった薬物 では，自己投与は同様に見られなかった。これらの 事実によって, 動物を用いた薬物自己投与法の研究 が，人間の薬物依存行動にきわめて有力な解析法で あることが明らかになり，薬物乱用を予測したりそ の治療法を研究するために利用されるようになって きたのである。

\section{3. 行動薬理学的手法による時間評価機構の 研究}

心理学のなかでもっとも重要なテーマのひとつと して, 動物やヒトの時間評価(time estimation) ${ }^{(\text {ii:2) }}$ にかかわる諸問題があげられる。時間と関係を持た ない学習はほとんどあり得ない。時間評価に関して は, 知覚・認知心理学の分野などからも研究されて いるが, 行動薬理学的にも, さまざまな向精神薬 とFI強化スケジュール住3) DRL スケジュール ${ }^{(\text {iit4) }}$ ぞの時間評価学習を用いて, 精力的な研究がなされ てきている。

アンフェタミンやメタンフェタミン (MPT)など の興奮剂を投与すると, DRL スケジュール課題で は, 反応数が増大し, 強化数が減少する ${ }^{12)-14)}$ 。DewS: 
control
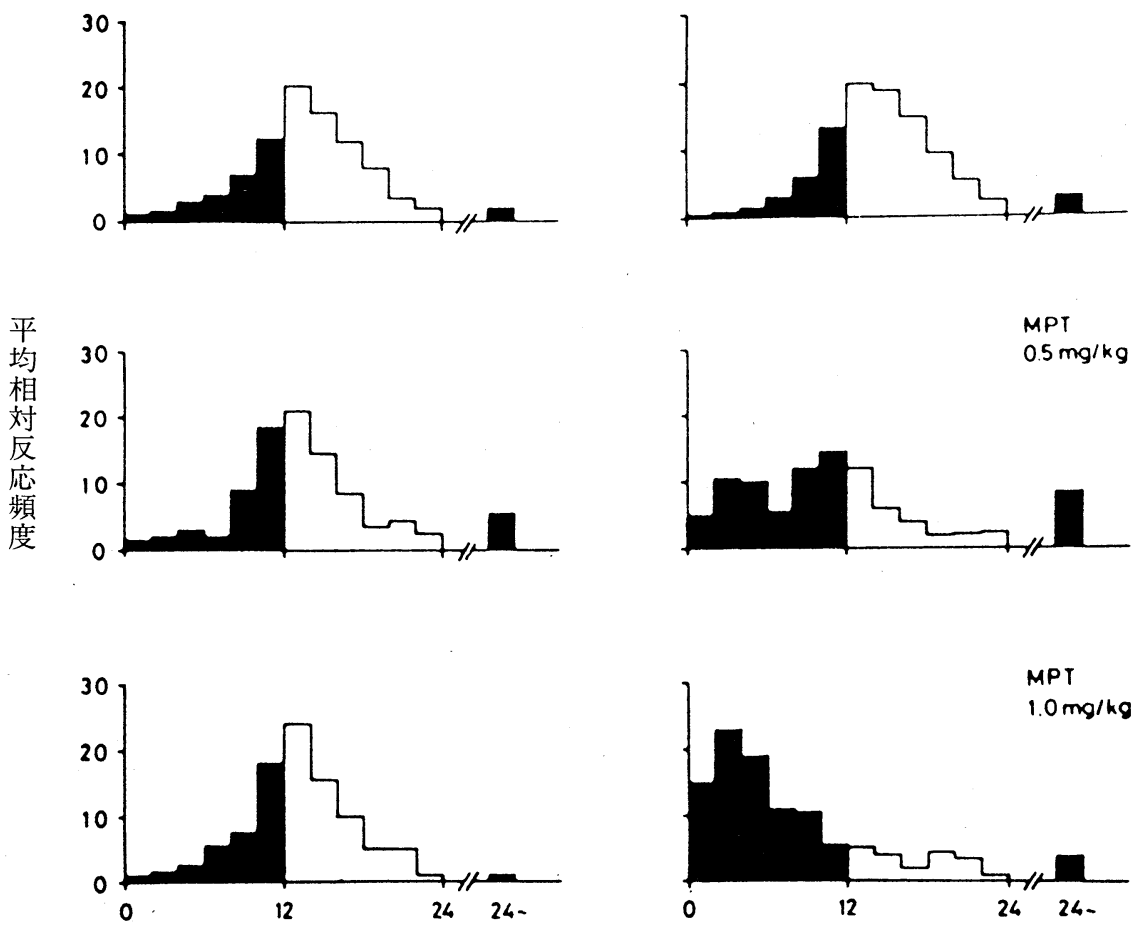

反応潜時（秒）

図 1 相対反応頻度分布に対するメタンフェタミン（MPT）の影響 左図は薬物投与直前の生理 食塩水条件, 右図は MPT 条件, (品) は非強化反応の相対頻度, ( $\square$ ）は強化反応の相対頻度をあ らわす ${ }^{14)}$ 。

とWenger ${ }^{15)}$ は，低頻度で反応していたネズミは， アンフェタミン投与によって高頻度で反応するょう になったが，逆に高頻度で反応していたネズミは， 低頻度で反応するようになると報告した。また F I 5 分の強化スケジュールでネコを訓練すると，アン フェタミンは反応頻度の低い FI 強化スケジュール訓 練の初期で反応数が増大し, 反応頻度の高いFI 強 化スケジュール訓練の末期で逆に減少させることも 見い出された ${ }^{16)}$ 。DRL スケジュール訓練事態ではオ ペラント反応の低頻度化を招くため，アンフェ夕ミ ンの作用によって反応頻度が増大するのかもしれな い (rate dependent theory)。さらにこれらの興奮 剂が，IRT (反応間間隔) を一般的には短縮させる ことも報告されている。これはIRTを媒介する定 型行動 (stereo typed behavior) が, アンフェタミ ンによって加速されたためと考えられている ${ }^{12), 17) 。 ~}$
アンフェタミンと類似の化学構造式を持ち, また 薬理作用も類似したメタンフェタミンによっても， 反応潜時 $(\mathrm{RT}, \mathrm{RL})$ の短縮化がおこる。われわれ はDRLL スケジュール(注5) を用い, メタンフェタ ミンが反応潜時分布を全体的に左へシフトさせるこ とを報告した (図 1$)^{14)}$ 。メタンフェタミン $1.0 \mathrm{mg} /$ $\mathrm{kg}$ (ip) では, ピークの反応頻度が維持されたまま 全体の型を保ちつつ, 分布が左へ平行にシフトして おり，反応潜時 $2 \sim 4$ 秒できわめて高頻度に反応し ている。このことは, 時間評価行動それ自体は消失 しておらず，体内時計の速度が増大している可能性 を示している18)。

アンフェタミンやメタンフェタミンとは逆に, 静 穞剤であるクロールプロマジンを投与した場合には, 反応潜時分布に顕著なつぶれが生じ，既成の時間評 価機構は一時的に培失している（図 2 )。これはクロ 

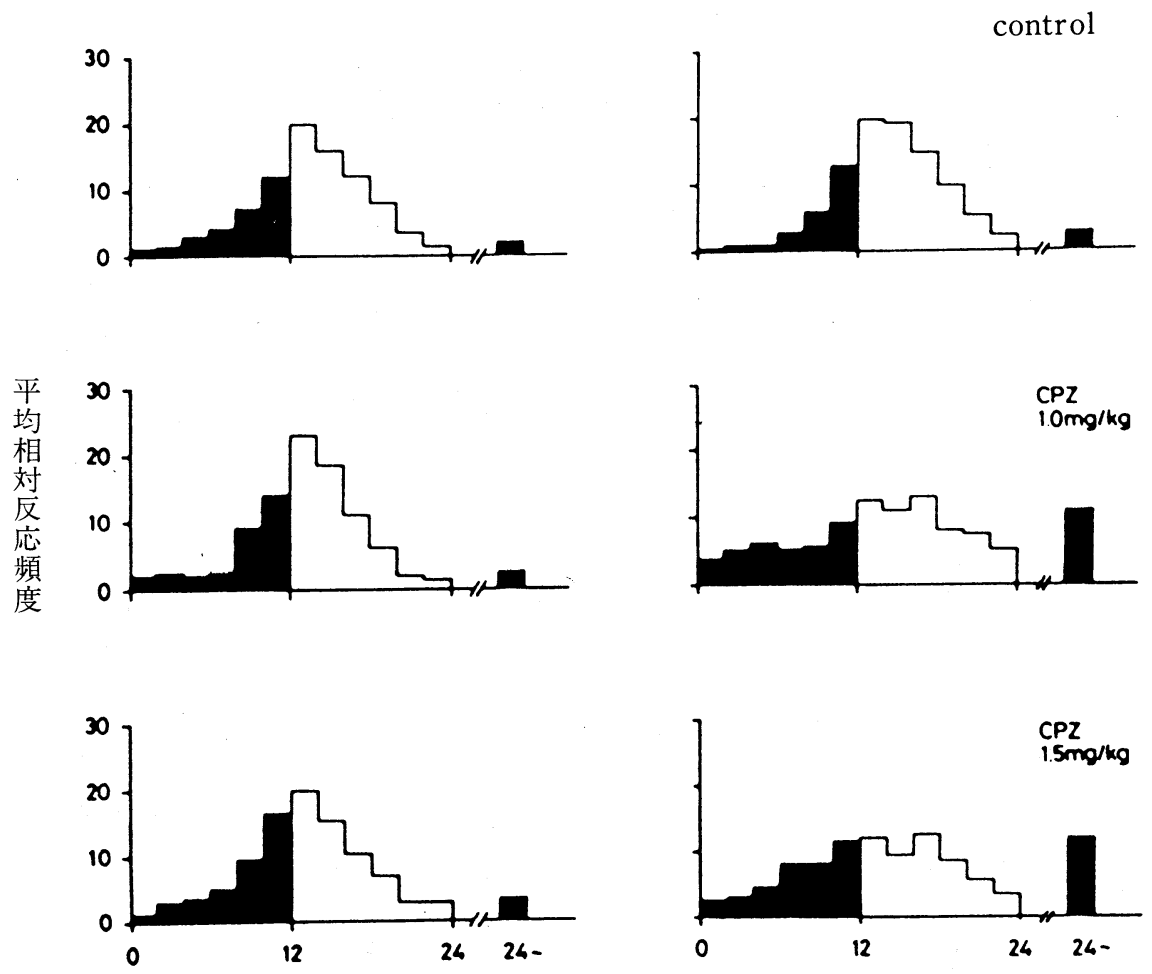

反応潜時（秒）

図 2 相対反応頻度分布に対するクロールプロマジン (CPZ) の影響 左図は薬物投与直前の生 理食塩水条件，右困は CPZ 条件，（口）は非強化反応の相対頻度，（ $\square ）$ は強化反応の相対頻度を あらわす14)。

ールプロマジンの静穏作用によって，時間評価行動 そのものが “鈍化した”可能性を示している。

時間評価に対するこれらの向精神薬の影響は，七 トについても多くの報告があり，たとえばカフェイ ン, アンフェタミン等の興奮剂が現在時間を長く評 価させ ${ }^{19)}$ ，バルビツール系の鎮静剤が逆に現在時間

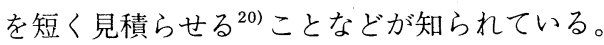

一方，アセチルコリン系ニューロンを遮断するス コポラミンも, やはり時間評価行動を阻害すること が知られている ${ }^{21)}$ 。KelseyとGrossman ${ }^{22)}$ は，往 復走路型の変型DRL 30 スケジュールを用い, スコ ポラミンの作用を分析した。この実験装置は，直線 走路の両端にゴールボックスを取り付け，その各々 の正対する壁面に梃子を装着したもので，ネズミは 一方のゴールボックスでの梃子押し反応が強化され ると，つぎの強化刺激を獲得するために，30秒間梃
子押し反応を抑制し，かつ走路の反対側のゴールボ ックスで，つぎの反応を解発しなければならなかっ た。この手続きでは, “失敗”反応をふたつの異なる タイプに分離することができ, 直前に強化を獲得し たのと同じゴールボックスで, 連続反応として出現 した“失敗”反応（固執エラー：perseverative errors）と，反対側のゴールボックスで出現したが， IRT が30秒に満たなかったために生じた“失敗”反 応（予測エラー：anticipatory errors）とした。実 験の結果，スコポラミンは予測エラーのみを増大さ せ，そのために強化反応数を減少させた。これは, スコポラミンが反応の抑制を阻害したためと考えら れた。一方，スコポラミンの作用をDRLL スケジ ユールで分析したわれわれの論文では, アンフェ夕 ミンやメタンフェタミンと同様に, 反応潜時分布の 型が保たれたまま全体的に左へシフトし, 時間評価 動物生理 


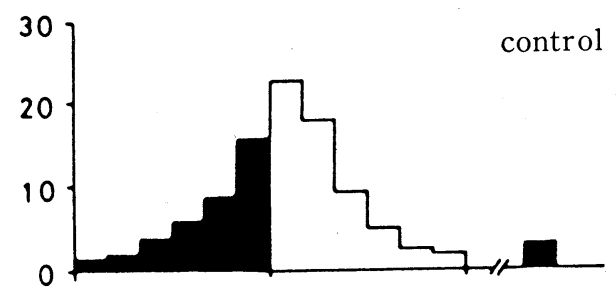

propylene
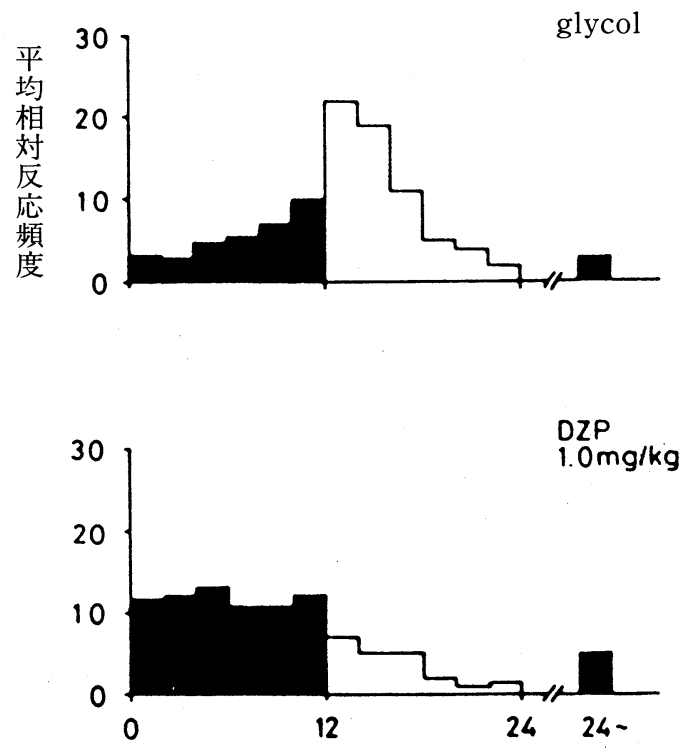

反応潜時（秒）
行動そのものは保存されていたと報告している ${ }^{23)}$ 。 抗不安薬では，クロルジアゼポキサイトやジアゼ パムなどのベンゾジアゼピンを投与すると, F I や DRL スケジュールで反応数を増大させ，時間評価 行動に障害があらわれた 14,16)，17)，24)-26)。われわれの 実験では，ジアゼパムがDRLL スケジュール課題 での反応数を増大させ，反応潜時分布を全体的に左 へシフトさせることを見い出した (図 3$)^{14)}$ 。しかし, アンフェタミンやメタンフェタミンの場合とは異な ク—これらの興奮剂では特定の反応潜時で高頻度 に反応する傾向が維持されていた（図 3 ), 反応潜 時分布困におけるピークが不明瞭になり，0〜12秒 間にわたっての短い反応潜時の反応が全体的に増大 している。このような事実などから，ジアゼパムは 活動性全般に対して影響を及ぼし，その行動に対す る非特異的な作用によって，結果的に時間弁別行動
図 3 相対反応頻度分布に対するジアゼパム（D Z P ）の影響 （回）は非強化反応の相対頻度,

（口）は強化反応の相対頻度をあらわす。 Propylene glycol はDZP の溶剂であり，この 溶剂の効果の検出のための統制群である ${ }^{14)}$ 。
をも阻害したのではないかと考えられる。またク口 ルジアゼポキサイトには, 筋肉弛緩作用 (muscle relaxant action) もあり，筋肉からの自己受容的 な刺激が遮断もしくは低減されたため, 時間評価行

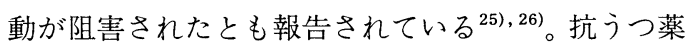
のイミプラミンを用いたわれわれの研究では, D R $\mathrm{LL}$ での反応数・強化数とも変化がなかったが, 反 応潜時分布がつぶれ，クロールプロマジンときわめ て類似した結果が得られた ${ }^{14)}$ 。

ところで以上に示したさまざまな末梢からの薬物 投与例では，薬物が被験体の全身に作用してしまい， 行動に影響を及ぼす薬物の効果を中枢にのみ限定す ることは困難である。これら末梢薬物投与法の持つ 難点を解決する方法のひとつに，薬物を直接脳内に 注入する方法がある。われわれは，カテコールアミ ン系ニューロンにのみ選択的変性をひきおこす, 神 


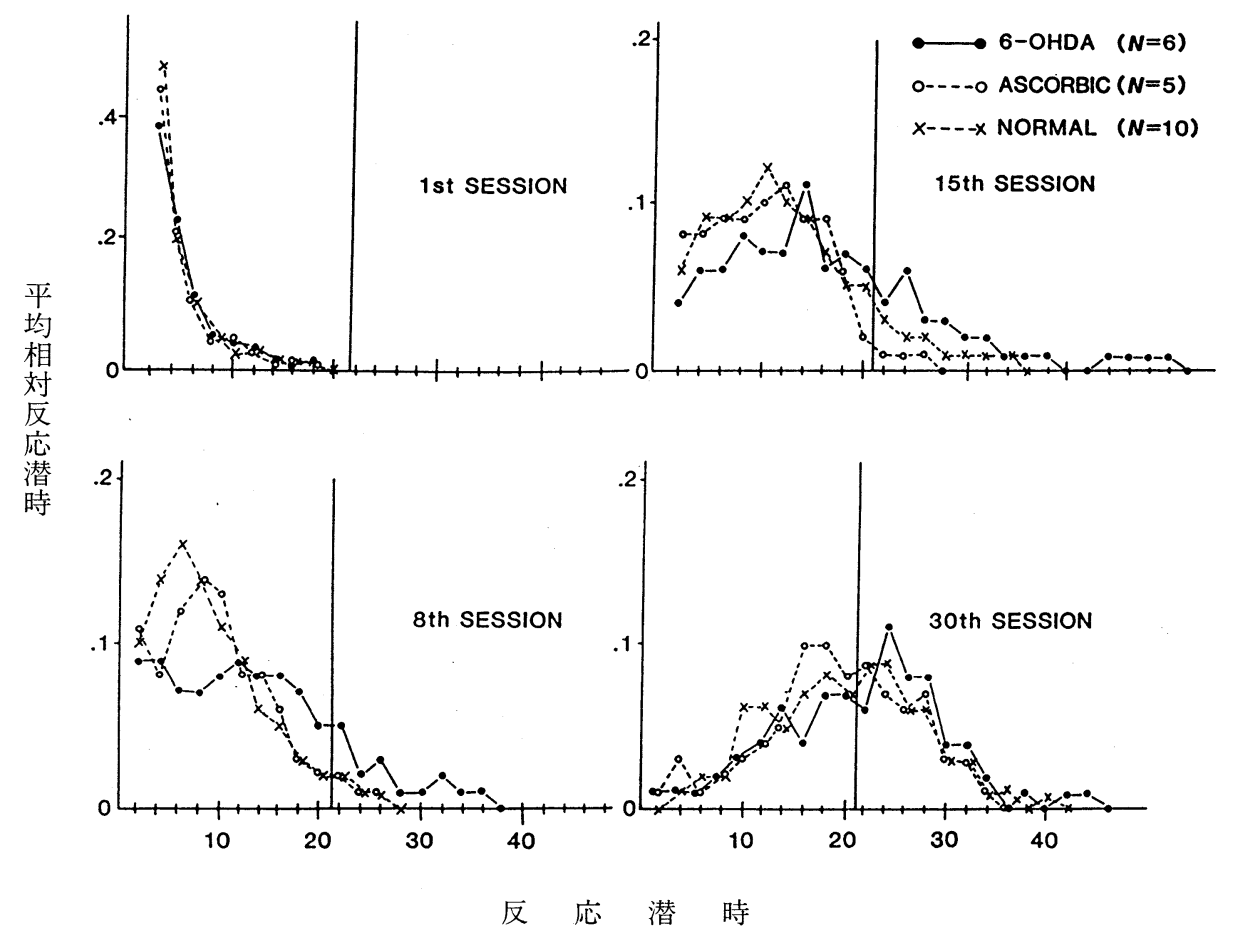

图 4 DRLL 20/L H 36訓練における相対反応頻度分布の変化 反応潜時20２2秒の間の垂直線 より右側の部分が強化反応の相対頻度をあらわし，左側の部分が非強化反応の相対頻度をあらわす。 ○一 - 6-OHDA 群 $(n=6)$; ○一○, アスコルビン酸群 $(n=5) ; \times — \times$, 非注入 群 $(n=10)$ 。アスコルビン酸群は， 6 -OHDA の酸化防上に用いたアスコルビン酸のみの影響を 調べるために設けられた27)。

経毒 6 一ハイドロキシドーパミンをネズミの中隔内 側部にステレオタキシスを用いて $(8 \mu g)$ 注入し, DRLL /LH スケジュールを用いて，オペラント反 応の抑制と時間評価行動の学習過程を分析した ${ }^{27)}$ 。 その結果，6ーハイドロキシドーパミン $(6-\mathrm{OH}$ DA ）を注入されたネズミでは，梃子押し反応の抑 制が促進され, 反応効率 (強化反応数/有効反応数) が増大した（図 4, 図 5 )。さらにまた，DRLL 時 間に満たない “失敗”反応の連発回数も減少した。 この事実は中隔のカテコールアミンニューロンが, オペラント反応の抑制に対して悪影響を及ぼしてい るのかもしれない。脳内微量注入法を用いた時間弁 別行動についての実験は, この他にもいくつか報告 されており ${ }^{28)-30)}$ ，いずれもネズミを被験体として前 述した変型 DRL スケジュールを用い, 失敗反応を 固執エラーと予測エラーに分離して分析している。
Kelsey ${ }^{28)}$ は，ネズミの中隔腹内側部・背外側部に

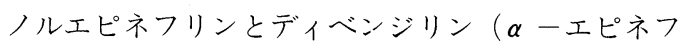
リンリセプター遮断薬) を注入した。腹内側部注入 では，ノルエピネフリンが予測エラーを増大させ， 強化反応数を減少させた。ディベンジリンは, 逆に 予測エラーを減少させ，強化反応数を增大させた。 一方，背外側部にノルエピネフリンを注入した場合 には, 予測エラーが減少し, 強化反応数が増大した。 ネズミの線条体にドーパミン，アンフェタミン，ス コポラミンを注入した場合には, IRT が短縮し, 固執 エラー・予測エラーともに増大した ${ }^{29)}$ 。海馬への微 量注入では, アセチルー $\beta$ ーメチルコリン（ムスカ リン性アセチルコリン様薬), ヒメカミラミン (ニコ チン性アセチルコリン遮断薬) が予測エラーを増大 させ, 強化数を低下させた。スコポラミンは予測エ ラー, 強化効率の両者をともに低下させた。一方, 


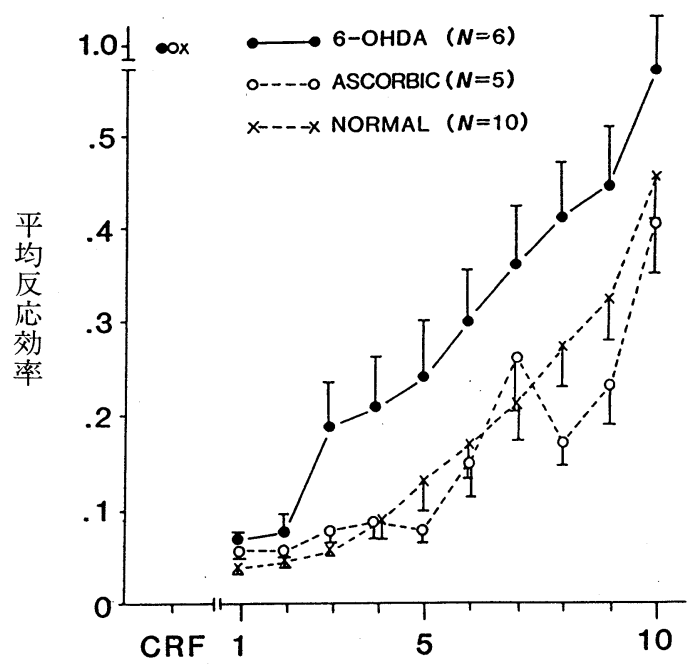

訓練ブロック（３セッションで1ブロック）

アセチルコリン系ニューロンを興奮させるニコチン

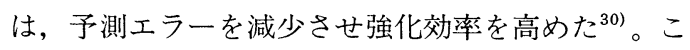
れは海馬のニコチン性機構とムスカリン性機構が, 行動抑制に対して相反する作用を及ぼし合っている ためではないかと考えられている。

\section{4. 行動薬理学の現状と艺の将来}

近年, 生化学的分析法が発達し, 中枢神経系の研 究はめざましい進歩を成し遂げつつある。螢光染色 法や免疫学的方法の発達によって, ドーパミンや， ルエピネフリンなどの特定神経伝達物質の局在性が 明らかにされ, 高速液体クロマトグラフィーや電気 化学検出器 (electrochemical detector)の利用に よって, 脳内の物質を 1 ナノグラム, さらには 1 ピ コグラムという極微量のオーダーで測定することが 可能になってきた。このように現在, 行動に対する 神経化学的側面に対しての関心がますます高まりつ つある。行動薬理学においても, たんに薬物と行動 との相互作用を分析するのみでなく，中枢における 薬物の作用機序・作用部位を考慮した，より微細な 検討が加えられている。たとえば，ある薬物と同じ 末梢作用を有しながら, 脳一血液関門を経過しない 別の薬物を統制条件として用いることにより，行動 の変化を薬物の中枢作用に帰因することが可能にな った。また, 脳内の特定部位に向精神薬や神経毒を
图 5 DRLL 20/LH 36訓練における反応効率(強 化反応数/有効反応数）の変化 各ブロックは 3 七 ッションを1ブロックとし，CRF は60OHDA 注入 直前のCRF 訓練最終セッションのもの。 6 -OHDA 群 $(n=6) ; \bigcirc \cdots \cdots .$. , アスコルビン 酸群 $(n=5) ; \times \cdots \cdots \times$, 非注入群 $(n=10)^{27)}$ 。

直接注入する脳内微量注入法の普及によって，中枢 の神経伝達物質と行動との関連性も, 脳の解剖学的 視点から明らかになりつつある。今後, 薬物の化学 構造とその行動作用との相関性の問題も行動薬理学 における重要なテーマのUとつとなるだろう ${ }^{31) 。 さ ~}$ らに, 薬物と脳内神経伝達物質との化学構造の類似 性・行動作用の類似性の問題等も検討する必要があ るだろう。

第 2 に，複雑化した現代社会にあって，われわれ の日常生活と薬物との関係がますます密接になりつ つあるという問題を取り上げることができる。

とりわけ抗不安薬や睡眠薬などは, 一般家庭でも 気軽に使用されるようになり，嗜好品である酒，夕 バコ，コーヒーなどは人間社会とは切っても切れな い“薬物”となっている。さらに先進諸国をゆるが す重大な社会問題となっている覚醒剤や有機溶剤の 乱用・嗜癖もあげられる。これらの薬物の多くは依 存性を有しており,「薬物依存性」をめぐる問題は, 行動薬理学研究者の重要な関心事のひとつとなって いる。動物や人間の薬物依存形成のメカニズムを解 明し, 薬物依存性がなくなおかつ臨床上の治療効果 を有する薬物を開発することが, 行動薬理学に期待 されている。

第 3 に，心身の病いの治療を目的とした薬物の開 発に対してはむろんのこと，今後，それらの予防を

Vol. 2, No. 1 (1985) 
目的とした薬物の開発に対しても，行動薬理学は積 極的に取り組むべきであろう。これまでの向精神薬 は，精神病をはじめとする異常行動の治療や修正を 目的として開発され，その有用性の判定に行動薬理 学は多大な貢献をしてきた。しかし，異常行動を治 療しそれを修正するのと同様に，正常な行動を制御 することにもまた有効であろう。これからの将来に おいてわれわれが，さまざまな薬物や毒物に暴露さ れると予想される事態に対して，もっとも適切な防 禦状態をつくりだし, 疾病や事故の発生を未然に防 ぐことも不可能ではなくなるだろう。

第 4 に，近年急速に関心が高まっている行動毒性 学への応用があげられよう。高度経済成長を達成し
た現在，産業廃棄物や有毒物質による環境污染が至 るところで発生し，国際的にもきわめて重大な社会 問題となっている。しかしながら，これら環境污染 物質の研究ははるかに立ち遅れており, 毒性を評価 ・検出し，さらには，いまだ明らかにされていない 物質の未知の毒性を予測できる試験法を確立するこ とが，早急に必要な課題となっている。

薬物の作用が多くは一過性で可逆的であるのに対 し，毒物の作用は不可逆的でしばしば致命的で死を 招く。これらの毒性評価のために独自の試験法を確 立する上で, 行動薬理学や行動毒性学に対して絶大 な期待が寄せられているが, これらの領域に対する オペラント心理学の貢献がますます求められている。

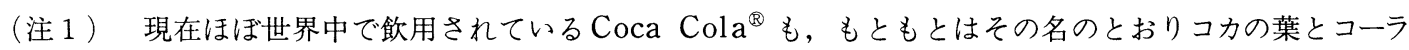
子 (Cola nitida またはCola acuminataの種子を乾燥させた生薬)の工キスを含んだ飲料であった。やが てコカイン中毒の恐ろしさに気付いたアメリカ政府はこの飲料からコカ成分を除去することをこの飲料の製 造会社に勧告し，長い論争の結果，コカ成分は除去されたが，その商品名はそのまま現在に至っている ${ }^{3)}$ 。

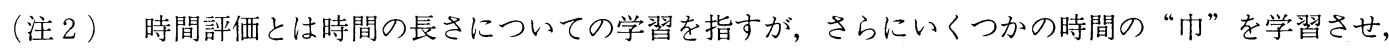
それぞれの時間の長さを区別させるような学習形態のときは，時間弁別 (time discrimination) 学習事態 と呼ばれることが多い。

(注 3 ）FI 強化スケジュールとは，ある強化反応から一定の時間の経過後の第 1 反応が強化されるといj 強化スケジュールである。たとえばFI 5 とは，ある強化反応から 5 分以上経過した第 1 反応に対して強化 刺激が提示される。 5 分に満たない時間に行なわれる反応に対しては強化刺激の提示はないが, このような 反応は強化可能時間の到着を遅らせることはない ${ }^{11)}$ 。

（注４） ある反応から一定の時間（DRL 時間）の経過後の第 1 反応のみが強化されるが, FI 強化スケジ ユールとは異なり，所定の時間に満たない反応はその経過時間をりセットさせ，ふたたび DRL 時間の計測 苏スタートする。たとえば DRL 20 とは DRL 時間が20秒であることを示し，ある反応から 20 秒かそれ以上 経過した反応に対してのみ強化が与えられる。

（注 5 ） 基本的には DRL スケジュールと同一であるが，経過時間のスタートが被験体の反応に依存する のではなく，実験者の設定したITI の終了によっている点が異なる。DRLL /LH とは経過時間に制限を 設けたスケジュールでDRLL 20/LH 10 とは，DRLL で20秒に達したのち10秒以内に反応された場合のみ 強化されることを意味している11)。

\section{文献}

1 ) 岩本降茂：異常行動研究会編 行動病理学ハン ドブック，p223-262, 誠信書房 (1969)

2) Ray, O. S . : Drugs, society, and human behavior, St. Louis, Mosby (1972)

3 ）山崎幹夫：自然, 460, 105-109（1984）

4 ) Zavadskii, I. V.: Trudy obshchestra Russkikh Vrachei-St. Petersburg, 75, 269-287 (1908)
5 ) Macht, D. I., Greenberg, J. \& Isaacs, S. : J. Pharmacol. exp. Ther., 15, 149-165 (1920)

6 ) Macht, D. I. \& Mora, C. F. : J. Pharmacol. exp. Ther., 16, 219-235 (1921)

7 ) Hofmann, A.: LSD-mein sorgenkind, Stuttgart : Klett-Cotta (1979) 福屋武人 (監), 堀正, 榎本博明: (訳), LSD幻想世界の旅, 東京, 水曜社 (1983)

8 ) Headlee, C. P., Coppock, H. W. \& Nichols, J. 
R. : J. Amer. pharmaceu. Assoc. (scientific edition), 44, 229-231 (1955)

9) Weeks, J. R.: Science, 138, 143-144 (1962)

10) Thompson, T. \& Schuster, C. R.: Psychopharmacologia, 5, 87-94 (1964)

11）岩本降茂：佐々木正信（編）現代基礎心理学 5 , p 115-149, 東京, 東京大学出版会 (1982)

12) Ahlenius, S. \& Engel, J.: Psychopharmacologia, 24, 243-246 (1972)

13) Robbins, T. W. \& Iversen, S. D. : Nature new Biol., 245, 191-192 (1973)

14）清水信一郎, 吉野弘, 岩本降茂, 早瀬雅彦: 動 物心理学年報, 30，40（1980）

15) Dews, P. B. \& Wenger, G. R. : in Advances in behavioral pharmacology, ed. T. Thompson \& P. B. Dews, 1. 167-277, New York, Academic Press (1977)

16) Richelle, M. : J. exp. Anal. Behav., 12, 989-998 (1969)

17) Sanger, D. J., Key, M. \& Blackman, D. E. :

Psychopharmacologia, 38, 159-171 (1974)

18) Maricq, A. V., Roberts, S. \& Church, R.M.: J. exp. Psychol. : animal behavior processes, 7, 18-30 (1981)

19) Frankenhaeuser, M.: Estimation of time, Stokholm, Allmqvist and Wiksell (1959)
20) Goldstone, S., Boardman, W. K. \& Lhaman, W. J. : Br. J. Psychol., 49, 324-328 (1958)

21) Kelsey, J. E. \& Grossman, S. P. (1970)

22) Kelsey, J. E. \& Grossman, S. P.: Pharmacol. Biochem. Behav., 3, 1043-1050 (1970)

23）和田博美, 吉野弘, 岩本降茂：基礎心理学研究, 1, 126 (1982)

24) McMillan, D. E. \& Campbell, R. J. : J. exp. Anal. Behav., 14, 177-184 (1970)

25) Richelle, M.: Arch. int. Pharmacodyn., 140, 434-449 (1962)

26) Richelle, M., Xhenseval, B., Fontaine, O. \& Thone, L. : Int. J. Neuropharmacol., 1, 381-391 (1962)

27）和田博美, 高橋憲男, 吉野弘, 岩本降茂: 薬物 - 精神・行動, 3，55-65（1983）

28) Kelsey, J. E. : Physiol. Psycol., 4, 433-438 (1976)

29) Neill, D. B. : Brain Res., 105, 89-103 (1976)

30) Ross, J. F. \& Grossman, S. P.: J. comp. physiol. psychol., 86, 590-600 (1974)

31) Thompson, T. \& Schuster, C. R.: Behavioral pharmacology, Prentice-Hall, Englewood Cliffs, N. J. (1968)

田所作太郎, 安東挲, 柳田知司 (訳), 行動薬理学, 東京, 岩崎学術出版（1968） 